\title{
URIARTE, Juan María: Una espiritualidad sacerdotal para nuestro tiempo. Santander: Sal Terrae, 2010.
}

\section{Uma espiritualidade sacerdotal para nosso tempo}

João Batista Libanio*

O ano sacerdotal, promulgado por Bento XVI, tem provocado a publicação de vários livros sobre a vida do sacerdote. Mons. Uriarte, bispo emérito de San Sebastián, Espanha, já vinha publicando obras sobre tal tema. O presente livro tem duas preocupações centrais: captar o desafio do momento atual e pensar a espiritualidade sacerdotal para ser vivida nele.

À guisa de introdução, dedica um capítulo ao tema da maturidade humana enfocando especialmente a pessoa do sacerdote. Parte de uma citação de João Paulo II da Exortação Apostólica pós-sinodal Pastores dabo vobis em que o Papa se refere à madureza psicológica, afetiva e sexual. Acentua a capacidade de sair de si, do próprio egoísmo e individualismo para sintonizar com o outro em três níveis. No nível mental, compreendendo-lhe a situação, o mundo interior, as aspirações, inseguranças, temores. No nível vital, estabelecendo com ele uma comunhão vital, uma empatia, especialmente com o seu sofrimento. E no nível da prática, deixando-se mobilizar pelo outro numa partilha de vida. A maturidade não termina nunca. Processo de toda a vida, movido por dois vetores: amar e trabalhar, segundo o fundador da psicanálise. Allport e Maslow acrescentam o lúdico (to play) e o religioso (to pray).

$\mathrm{O}$ autor aponta seis características maiores da maturidade: conhecimento das próprias possibilidades e limites, conhecimento do outro sem idealizações ou satanizações, unidade interior bem integrada - razão, desejo, pulsões, valores, ideais -, orientação unificada, capacidade de amar com um amor que ultrapassa o narcisismo para a

\footnotetext{
* Doutor em Teologia (Gregoria-Roma) e professor da FAJE (Faculdade Jesuíta de Filosofia e Teologia). Email: secteologia@faculdadejesuita.edu.br
}

Horizonte, Belo Horizonte, v. 8, n. 19, p. 154-157, out./dez. 2010 
oblatividade e a adesão a valores transcendentes. O narcisismo representa o reverso da madureza afetiva.

No interior do círculo da maturidade afetiva, situa-se a sexual com a dimensão biológica, biopsíquica das pulsões e componente psicológico. $\mathrm{O}$ movimento de tal madureza vai em direção de uma relação com o outro, que supere a tendência fusional e relações calcadas no passado, que faça convergir sensibilidade e ternura na pessoa desejada, que manifeste reciprocidade ultrapassando idealizações ou demonizações, que garanta fidelidade.

Como toda maturidade humana, o sacerdote desenvolve a própria pelo amor e trabalho, pelo desejo e projeto de uma vida sacerdotal, vinculada à Igreja, enfrentando as dificuldades específicas de sua vocação. No momento, pesam-lhe a deslegitimação social da função presbiteral, a dificuldade de fundá-la na base vital do sujeito por desconhecer a verdade dos próprios desejos profundos, a perda ou crise do protagonismo pastoral em face de tantos outros participantes, os fracassos ou resultados pífios depois de muito esforço e trabalho pastoral.

Ao concluir essa longa iniciação ao tema central, o autor aponta tarefas e pontos de apoio para alcançar a maturidade nos níveis psicológico, afetivo, sexual e espiritual. Por suposto, está a oração, válida para todos e ao longo de toda a vida. Além dela, impõe-se uma identificação profunda com a própria vocação e missão para além de simples tarefa, profissão ou desempenho institucional, isto é, sentir-se existencialmente presbítero. Para isso ajudam manter uma comunicação transparente com adulto livre e respeitoso, manter no comportamento o equilíbrio entre a interioridade e exterioridade, clarificar e purificar as motivações, aprender de maneira existencial a linguagem do amor célibe.

Ao tocar o coração do tema, o autor desenvolve uma espiritualidade sacerdotal para os dias de hoje. Aborda-a em treze parágrafos quase todos em perspectiva dialética.

Num primeiro bloco, propõe uma espiritualidade da confiança e não do otimismo. A realidade futura nem sempre se apresenta rósea. Mas nada nos abala a firmeza posta em Deus. Em tempos difíceis, ela se aferra ao pequeno, sem, porém, suspirar pelo grande. Postos num mundo de extrema agitação e hiperatividade, o sacerdote alimenta um fazer sossegado, porque sustentado pelo Espírito. Imerso no presentismo pós-moderno, ele nutre um ritmo de vida respeitoso da herança do passado e atento aos sinais do futuro. 
Em outro bloco, insiste na fidelidade em vez do sucesso e triunfo. Ela pede responsabilidade, sem, no entanto, carregar o sacerdote com culpabilização doentia. Os entraves espirituais e pastorais crescem. Em face deles, cabe atitude espiritual de certa paciência, sem açodamentos. As pessoas hoje pedem e esperam do sacerdote proximidade, sintonia antes que distância e alheamento. Na mesma linha, o sacerdote toca os fieis preferentemente pela alegria, pela transparência afetiva, pela bondade à tristeza, à casmurrice.

Fechando o capítulo num terceiro grupo de traços para a espiritualidade sacerdotal, indica quatro pontos. Privilegia-se o cuidado da experiência de preferência à precisão dogmática. A comunhão prevalece sobre a autarquia. Prefere curar a denunciar, a condenar. E finalmente aprende-se e ensina-se a rezar.

O terceiro capitulo trabalha a fraternidade sacerdotal. Realidade relevante, necessária, embora difícil de criar. Ela produz maior eficiência apostólica, alimenta saúde integral do clero e dá exemplo para a comunidade. Embora válidas, tais razões não bastam. Há outras mais importantes. A teologia do ministério presbiteral afirma a unidade da comunidade dos presbíteros e sua vinculação com o colégio episcopal. Realiza a verdadeira fraternidade sacramental, apoiada no único sacramento da ordem, na única missão apostólica, no único Espírito recebido na ordenação. E para o presbítero diocesano, o presbitério oferece lugar eminente de fraternidade presbiteral como sinal da fraternidade de toda a Igreja diocesana.

Não faltam empecilhos, tais como, a dispersão geográfica, a autonomia das paróquias, a diversidade de mentalidades e interesses do clero, a relativa distância das instâncias diocesanas, as deficiências na formação dos seminários.

O celibato mereceu reflexão à parte. Pesam alguns condicionamentos desfavoráveis. Vive-se num mundo de sobrecarga de estímulos eróticos. A mentalidade dominante mostrase adversa. E some-se o predomínio do narcisismo, de ideais de baixa intensidade. $\mathrm{O}$ celibato cristão surgiu como contracultura em relação ao judaísmo e ao mundo grego. Mas se misturaram a ele motivos espúrios, que provocam críticas. A vocação ao celibato carece de recolocá-lo na correnteza límpida dos inícios. Como paradigma de todo celibato cristão lá está o exemplo de Jesus. Este se funda no Absoluto de Deus Pai, no valor e na urgência do Reino de Deus, na entrega à comunidade que promove o Reino. 
Avança a reflexão apontando traços importantes da espiritualidade do celibato. É trinitária. Ao aceitar de forma existencial a Deus na sua alteridade, reconhece nele a plenitude do humano. E ao voltar-se para Jesus, inverte o sinal e reconhece no seguimento a maneira humana de viver o divino. Tal existência alternativa se vive na força do Espírito Santo. Em relação ao Reino de Deus, o celibato revela-lhe determinados valores. Respeito à comunidade eclesial, sinaliza uma expressão de amor para com ela com o toque da opção preferencial pelos pobres. Por ele, se renuncia o poder. Numa palavra, ele revela sentido profético.

Não se vive o celibato com qualquer tipo de vida. Situa-se no contexto do seguimento de Jesus. Apóia-se na graça de Deus que acompanha o célibe ao longo de toda a vida, sobretudo para assumir positivamente a solidão própria dessa vocação de coração inteiro. Implica conjugar comunicação e sobriedade. A oração faz-se necessária em todos os momentos.

O livro termina com um capítulo sobre a fidelidade. Deus é fiel. Dado bíblico fundamental. Corresponde de nossa parte a fidelidade a Cristo. Espreitam o celibatário várias patologias: vida dupla, mecanicismo, mediocridade, fidelidade intermitente e fidelidade básica, sem, porém a radicalidade evangélica. A fidelidade evangélica é humilde, modesta, progressiva, concreta, realista e agradecida.

Livro direto, sincero, honesto e esclarecido. Equilibra bem o realismo de quem conhece os meandros da vida celibatária dos sacerdotes por longa experiência de bispo próximo a eles com traços de esperança, de grandeza espiritual. Mostra tanto a beleza do celibato como as dificuldades e contrafações. Oferece excelente material de reflexão e meditação para encontros de sacerdotes. Bastante conciso permite que se avancem as considerações. 